\title{
Correction to: Multiple Articles in Acta Parasitologica
}

\author{
Springer International Publishing ${ }^{1}$
}

Published online: 13 January 2022

(c) The Author(s) under exclusive licence to Witold Stefański Institute of Parasitology, Polish Academy of Sciences 2022

\section{Correction to: Acta Parasitologica \\ https://doi.org/10.1007/s11686-021-00489-y \\ https://doi.org/10.1007/s11686-021-00491-4}

The copyright holder for these articles was incorrectly given as 'The Author(s), under exclusive licence to The Author(s) under exclusive licence to Witold Stefański Institute of Parasitology, Polish Academy of Sciences' but should have been 'The Author(s) under exclusive licence to Witold Stefański Institute of Parasitology, Polish Academy of Sciences'. The original articles have been corrected.

Publisher's Note Springer Nature remains neutral with regard to jurisdictional claims in published maps and institutional affiliations.

The original articles can be found online at https://doi.org/10. 1007/s11686-021-00489-y and https://doi.org/10.1007/s11686021-00491-4. 